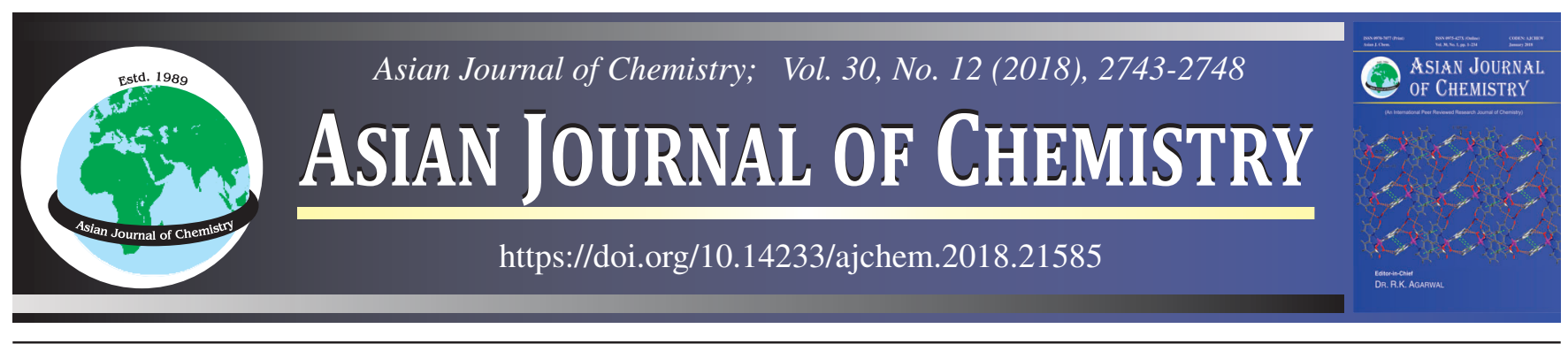

\title{
Spectral Characterization and X-Ray Crystallographic Studies of Some Triphenyltin(IV) Dithiocarbamates Compounds
}

\section{Rapidah Mohamad ${ }^{1}$, Normah Awang ${ }^{2, *}$, Nurul Farahana Kamaludin ${ }^{2}$ and Norraphat Uttraphan Pim ${ }^{1}$}

${ }^{1}$ Biomedical Science Programme, School of Diagnostic and Applied Health Sciences, Faculty of Health Sciences, Universiti Kebangsaan Malaysia, Jalan Raja Muda Abdul Aziz, 50300 Kuala Lumpur, Malaysia

${ }^{2}$ Environmental Health and Industrial Safety Programme, School of Diagnostic and Applied Health Sciences, Faculty of Health Sciences, Universiti Kebangsaan Malaysia, Jalan Raja Muda Abdul Aziz, 50300 Kuala Lumpur, Malaysia

*Corresponding author: E-mail: norm@ukm.edu.my

Received: 16 July 2018; Accepted: 27 September 2018; Published online: 31 October 2018;

Three novel triphenyltin(IV) compounds with $N$-(2-methoxyethyl)- $N$-methyldithiocarbamate (1), $N$-benzyl- $N$-phenethyldithiocarbamate (2) and $N$-methyl- $N$-hexyldithiocarbamate (3) ligands have been successfully synthesized via in situ insertion method. The newly synthesized compounds gave fairly sharp melting points indicating their purity and were successfully isolated as crystalline solids. All the compounds have been characterized by CHNS elemental analysis, FT-IR, ${ }^{1} \mathrm{H},{ }^{13} \mathrm{C}$ and ${ }^{119} \mathrm{Sn}$ NMR spectroscopies. A single C-S vibration band around $1000 \mathrm{~cm}^{-1}$ was observed in all compounds, suggesting bidentate bonding of dithiocarbamate ligand to tin metal through both sulfur donor atoms. The crystal structures of all the compounds were determined by X-ray crystallography. All the compounds were crystallized in triclinic system having PI space group. The single crystal X-ray diffraction data illustrated all three dithiocarbamato ligands are bidentate but in asymmetric fashion due to $\Delta(\mathrm{Sn}-\mathrm{S})$ bond length and the geometry at the tin center is described as distorted trigonal-bipyramidal.

Keywords: Triphenyltin(IV), Dithiocarbamates, X-ray crystallography.

ᄂ - - - - - - - - - - - - - - - - - - - - - - - - - - - - -

\section{INTRODUCTION}

Dithiocarbamate (DTC), a four-electron donating ligand that is capable of either $\pi$-electron donation or withdrawal, has played a role in the study of a wide variety of compounds. This monoanionic ligand has been used in the synthesis of lower and higher oxidation state transition metal compounds [1]. The ability of the ligand to adopt dithiocarbamate and thioureide tautomers gives it unique properties to stabilize both low- and high-valent metal ions (Fig.1). The dithiocarbamate form (A) is considered as a soft ligand that is capable in binding to low-valent metal atoms such as tin, while extra negative charge localized on sulfur in the thioureide tautomer (D) is best described as a hard ligand and best suited to high-valent metal binding [2].

The coordination geometry of tin atom in the complexes may be tetrahedral, trigonal-bipyramidal, square-pyramidal, octahedral or pentagonal bipyramidal, depending on the number of organic groups, the coordination mode of $\mathrm{CS}_{2}$ moiety and the number of ligands attached to tin atom [3]. It is worth mentioning that organotin derivatives have a wide range of applications, from agriculture and biology, to catalysis and organic synthesis [4]. Organotin compounds are mostly known for their biocidal effects and have been widely used as wood preservatives, acaricides, disinfectants, bactericides, fungicides, molluskicides, PVC stabilizers, and marine antifouling products [5]. Since, serendipitous discovery of the antiproliferative activity of cisplatin; which was the first metal-containing anticancer drug, much effort have been shifted to the design of new metalbased drugs for oncology therapies [6]. Tin complexes are proposed to have therapeutic potential as alternatives to cisplatin and similar anticancer agents [5] since platinum and tin atoms possess common chemical properties [7]. The antitumor activity of several tin based compounds have also been investigated and reported, which sparked an interest in tin compounds [5]. A large number of organotin(IV) compounds have been tested in vitro and in vivo, firstly against murine leukemia cell lines, followed by different panels of human cancer cell lines [8].

This is an open access journal, and articles are distributed under the terms of the Creative Commons Attribution-NonCommercial 4.0 International (CC BY-NC 4.0) License, which allows others to copy and redistribute the material in any medium or format, remix, transform, and build upon the material, as long as appropriate credit is given and the new creations are licensed under the identical terms. 


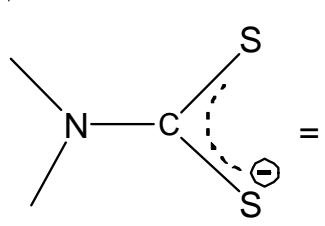

A

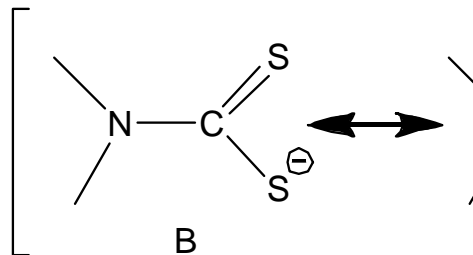

B

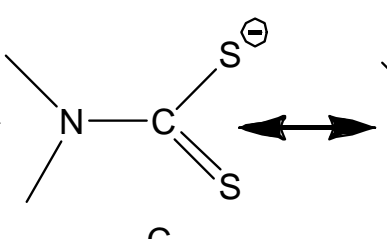

C

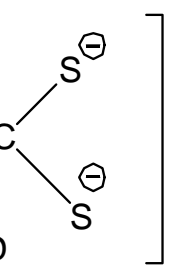

Fig. 1. Resonance forms of the dithiocarbamic -NCSS- moiety

In general, the cytotoxic activity of organotin(IV) compounds is influenced by the organotin moiety, ligand and coordination number of tin atoms [3]. Their toxicity decreases in the order $\mathrm{R}_{3} \mathrm{SnX}>\mathrm{R}_{2} \mathrm{SnX}_{2}>\mathrm{RSnX}_{3}$ [9]. The literatures have shown that the triphenyltin(IV) derivatives possess higher cytotoxic effects as compared to diorganotin(IV) derivatives at various concentrations when tested on different types of cancer cells [10]. Thus, the design and synthesis of new organotin(IV) dithiocarbamate compounds are encouraged by changing ligands and organotin substrates. In order to continue the expansion of structural chemistry of organotin(IV) dithiocarbamate compounds, we have synthesized three new triphenytin(IV) compounds with $N$-(2-methoxyethyl)- $N$-methyldithiocarbamate (1), $N$-benzyl$\mathrm{N}$-phenethyldithiocarbamate (2) and $\mathrm{N}$-methyl- $\mathrm{N}$-hexyldithiocarbamate (3) ligands. Herein, we report the synthesis, spectral characterization and X-ray crystallographic study of these three triphenyltin(V) dithiocarbamate compounds.

\section{EXPERIMENTAL}

All the chemicals and solvents were purchased from SigmaAldrich and Merck and used without purification. The melting points were determined using an automated melting point apparatus (MPA 120 EZ-Melt). The percent compositions of the elements (CHNS) for the compounds were determined using a Leco CHNS-932 elemental analyzer. The infrared spectra were recorded as potassium bromide discs using a Perkin Elmer Spectrum GX in the range of 4000 to $370 \mathrm{~cm}^{-1}$. The ${ }^{1} \mathrm{H},{ }^{13} \mathrm{C}$ and ${ }^{119} \mathrm{Sn}$ nuclear magnetic resonance (NMR) spectra were recorded at room temperature on a Bruker AVANCE 400111 HD instrument with deuterated chloroform $\left(\mathrm{CDCl}_{3}\right)$ as solvent and tetramethylsilane as an internal standard. Chemical shift values are given in parts per million (ppm) quoted with respect to the residual protons/carbon of the solvent signals for $\mathrm{CDCl}_{3}$ at 7.24 and $77.0 \mathrm{ppm}$ for ${ }^{1} \mathrm{H}$ and ${ }^{13} \mathrm{C}$, respectively, while ${ }^{119} \mathrm{Sn}$ NMR data are given. Crystal structure determination was carried out on a Bruker Smart Apex II. All data collection was carried out at $139-169 \mathrm{~K}$.

Synthesis of triphenyltin(IV) dithiocarbamates compounds (Fig. 2): $N$-(2-methoxyethyl)- $N$-methylamine (1.1 mL, 10 mmol), $N$-benzyl- $N$-phenethylamine $(2.1 \mathrm{~mL}, 10 \mathrm{mmol})$ and $\mathrm{N}$-methyl- $\mathrm{N}$-hexylamine $(1.52 \mathrm{~mL}, 10 \mathrm{mmol})$ dissolved in ethanol $(30 \mathrm{~mL})$ was stirred for $30 \mathrm{~min}$. After that, carbon disulphide $\left(\mathrm{CS}_{2}\right)(0.6 \mathrm{~mL}, 10 \mathrm{mmol})$ in cold ethanol was slowly added and the resulting mixture was stirred for the next $2 \mathrm{~h}$. Ammonia solution $(25 \%, 1-2 \mathrm{~mL})$ was added to generate a basic condition. Then, triphenyltin(IV) chloride ( $3.85 \mathrm{~g}, 10 \mathrm{mmol})$ dissolved in ethanol was added dropwise into the solution and stirred for 2 h. All the reactions were carried out at under $4{ }^{\circ} \mathrm{C}$. The precipitate formed was dried and collected.

Recrystallization and X-ray crystallography: Recrystallization was achieved by dissolving the compound in a chloroform and ethanol mixture with ratio $(1: 2 \mathrm{v} / \mathrm{v})$ for compound 1 and $(1: 1 \mathrm{v} / \mathrm{v})$ for compounds 2 and $\mathbf{3}$. This solution was allowed to slowly evaporate at room temperature yielding colourless crystals. Data collection: CrysAlis PRO10, cell refinement: CrysAlis PRO11, Data reduction: CrysAlis PRO [11]. Program(s) used to solve structure: SHELXL97 [12]. Program(s) used to refine structure: SHELXL2014 [13]. Molecular graphics: ORTEP-3 for Windows [14] and DIAMOND [15]. The range of theta for data collections together with other crystallographic information are given in Table-1.

\section{RESULTS AND DISCUSSION}

Synthesis of triphenyltin(IV) dithiocarbamate compounds: Compounds 1-3 were synthesized from the corresponding secondary amines, $\mathrm{CS}_{2}$ and triphenyltin(IV) chloride in ethanol.

TABLE-1

CRYSTALLOGRAPHIC PARAMETERS FOR THE TRIPHENYLTIN(IV) COMPOUNDS 1-3

\begin{tabular}{llll}
\hline Crystal data & Compound 1 & Compound 2 & Compound 3 \\
\hline Gross formula & $\mathrm{C}_{23} \mathrm{H}_{25} \mathrm{NOS}_{2} \mathrm{Sn}$ & $\mathrm{C}_{34} \mathrm{H}_{31} \mathrm{NS}_{2} \mathrm{Sn}$ & $\mathrm{C}_{26} \mathrm{H}_{31} \mathrm{NS}_{2} \mathrm{Sn}$ \\
$\mathrm{M}$ & 514.3 & 636.47 & 540.38 \\
Crystal system & Triclinic & Triclinic & Triclinic \\
Space group & $\mathrm{PI}$ & $\mathrm{PI}$ & $\mathrm{P} \overline{\mathrm{I}}$ \\
Crystal shape & Slab & Slab & Block \\
Colour & Colorless & Colorless & Colorless \\
$\mathrm{a}, \mathrm{b}, \mathrm{c}(\AA)$ & $7.6258(3), 10.2178(3), 14.8621(6)$ & $9.5856(2), 11.6140(2), 13.6795(3)$ & $9.8590(6), 10.4256(5), 14.3960(8)$ \\
$\alpha, \beta, \gamma\left({ }^{\circ}\right)$ & $91.976(3), 90.655(3), 107.875(3)$ & $78.043(2), 77.868(2), 82.358(2)$ & $110.557(5), 94.057(5), 110.730(5)$ \\
$\mathrm{V}\left(\AA^{3}\right)$ & $1101.19(7)$ & $1450.20(5)$ & $1263.24(13)$ \\
$\mathrm{Z}$ & 2 & 2 & 2 \\
$\mathrm{~T}(\mathrm{~K})$ & 148 & 139 & 169 \\
Crystal size $(\mathrm{mm})$ & $0.5 \times 0.3 \times 0.3$ & $0.50 \times 0.30 \times 0.20$ & $0.3 \times 0.2 \times 0.05$ \\
Reflections with $\mathrm{I}>2 \sigma(\mathrm{I})$ & 6089 & 8428 & 4580 \\
$\mathrm{R}_{\text {int }}$ & 0.046 & 0.038 & 0.043 \\
\hline
\end{tabular}




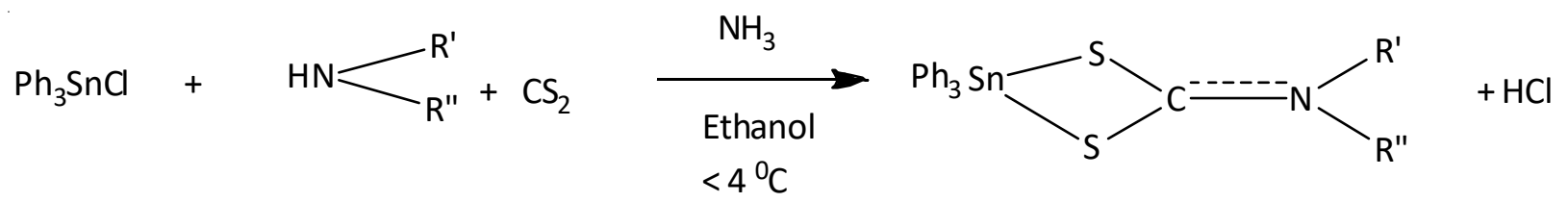

Fig. 2. General equation for the preparation of triphenyltin(IV) compounds with their respective dithiocarbamate ligands

\begin{tabular}{|c|c|c|c|c|c|c|}
\hline \multirow{3}{*}{ Compound } & \multicolumn{5}{|c|}{$\begin{array}{r}\text { TABLE-2 } \\
\text { PHYSICAL AND ELEMENTAL ANAL }\end{array}$} & \\
\hline & \multirow{2}{*}{ Yield $(\%)$} & \multirow{2}{*}{ m.p. (K) } & \multicolumn{4}{|c|}{ Elemental analysis (\%): Found (calcd.) } \\
\hline & & & $\mathrm{C}$ & $\mathrm{H}$ & $\mathrm{N}$ & $\mathrm{S}$ \\
\hline 1 & 78 & $366.3-366.8$ & $54.3(53.71)$ & $5.3(4.9)$ & $2.7(2.72)$ & $12.5(12.47)$ \\
\hline 2 & 85 & $419.0-421.0$ & $64.5(64.20)$ & $5.3(4.9)$ & $2.3(2.20)$ & $9.9(10.10)$ \\
\hline 3 & 52 & $364.6-365.4$ & $56.5(57.80)$ & $6.2(5.8)$ & $2.5(2.60)$ & $11.7(11.90)$ \\
\hline
\end{tabular}

All three compounds are white in colour and their crystals are colourless. These compounds are stable in air and highly soluble in chloroform. The elemental analyses obtained are in good agreement with the proposed molecular formulae as presented in Table-2.

Infrared spectroscopy: Solid state infrared spectra of the compounds have been recorded in the range 4000-375 $\mathrm{cm}^{-1}$ and the most important bands are presented in Table-3. From the data, the absorption in the range $1498-1477 \mathrm{~cm}^{-1}$ was assigned to thioureide $v(\mathrm{C}-\mathrm{N})$ vibration which can also be found in other chelated dithiocarbamates $[10,16]$. This thioureide band arises from the stretching vibration of $\mathrm{C}-\mathrm{N}$ bond with a partial double bond and polar character, $\mathrm{C}=\mathrm{N}^{+}$and is normally present at 1500 $1450 \mathrm{~cm}^{-1}$ [17]. The stretching vibration peaks of C-N in the studied complexes lie between the range of $\mathrm{C}-\mathrm{N}$ single bonds $\left(1360-1250 \mathrm{~cm}^{-1}\right)$ and $\mathrm{C}=\mathrm{N}$ double bond $\left(1690-1640 \mathrm{~cm}^{-1}\right)$ which is an indication of partial double bond character in the C-N bond [18]. The thioureide bands in compounds 1-3 appeared near the higher frequency, showing a stronger carbon-nitrogen double bond character and hence, exhibiting a greater contribution to structure D (Fig. 1).

TABLE-3

IMPORTANT IR ABSORPTION BANDS OF THE COMPOUNDS

\begin{tabular}{ccccc}
\hline \multirow{2}{*}{ Compound } & \multicolumn{4}{c}{ IR spectra $\left(\mathrm{cm}^{-1}\right)$} \\
\cline { 2 - 5 } & $v(\mathrm{C}-\mathrm{N})$ & $v(\mathrm{C}-\mathrm{S})$ & $v(\mathrm{Sn}-\mathrm{C})$ & $v(\mathrm{Sn}-\mathrm{S})$ \\
\hline 1 & 1477 & 997 & 527 & 451 \\
2 & 1476 & 1021 & 502 & 448 \\
3 & 1498 & 983 & 530 & 445 \\
\hline
\end{tabular}

The $v(\mathrm{C}-\mathrm{S})$ vibration that appears in the range 1050-950 $\mathrm{cm}^{-1}$ can be used to determine the chelation nature of the dithiocarbamate ligand, which is monodentate or bidentate $[17,19]$.
The set of - $\mathrm{CS}_{2}$ fragments are unique since they provide information of the coordination mode of the complexes [4]. The bands due to -CSS are usually coupled to other vibrations and are very sensitive to the environment around this group, but they are also useful to distinguish between mono- and bidentate coordination [20]. The presence of a single band in the $v(C-S)$ region is an indication of bidentate character whereas the presence of two bands with separation value $>20 \mathrm{~cm}^{-1}$ suggests that ligand bonding is monodentate [18]. In present study, the appearance of single bands for C-S in compounds 1-3 suggested the bidentate bonding of dithiocarbamato ligands to $\mathrm{Sn}$ center.

Another important peak observed in the infrared spectrum is the signal for $\mathrm{v}(\mathrm{Sn}-\mathrm{C})$ that usually occurs in the range of 600 $500 \mathrm{~cm}^{-1}$ [4]. The peaks within the range $527-502 \mathrm{~cm}^{-1}$ signify the presence of Sn-C stretching bands for compounds with phenyl moiety. The next region is at the lower frequencies (450-250 $\mathrm{cm}^{-1}$ ) which is attributed to the vibration of $\mathrm{Sn}-\mathrm{S}$ bond [4], suggesting the complexation of organotin moiety with the dithiocarbamate ligands which appeared at $451-445 \mathrm{~cm}^{-1}$.

NMR spectroscopy: ${ }^{1} \mathrm{H}$ NMR spectra of all the compounds were recorded in $\mathrm{CDCl}_{3}$ solution and tetramethylsilane is used as an internal standard at room temperature. The chemical shifts (ppm) of the various observed protons are presented in Table-4. The aromatic protons of phenyl groups directly attached to Sn atom in compounds $\mathbf{1}, \mathbf{2}$ and $\mathbf{3}$ were observed at 7.414-7.821, 7.439-7.861 and 7.278-7.767 ppm, respectively. In addition, ${ }^{1} \mathrm{H}$ NMR spectrum of compound 1 showed two triplets at 4.051 and $3.719 \mathrm{ppm}$ which were assigned to the methylene protons bound to nitrogen and oxygen. Two singlets at 3.514 and 3.376 have been attributed to the terminal methyl protons. In compound 2, a multiplet was observed at 7.163-7.393 ppm corresponding to the presence of aromatic protons of benzyl groups. The methylene protons of benzyl group appeared as a singlet at 5.031

\begin{tabular}{|c|c|c|c|}
\hline \multicolumn{4}{|c|}{$\begin{array}{c}\text { TABLE-4 } \\
{ }^{1} \mathrm{H} \text { NMR AND }{ }^{119} \mathrm{Sn} \text { NMR DATA }\end{array}$} \\
\hline \multirow{2}{*}{ Compound } & \multicolumn{2}{|r|}{${ }^{1} \mathrm{H}$ NMR $(\mathrm{ppm})$} & \multirow{2}{*}{$\begin{array}{l}{ }^{119} \mathrm{Sn} \mathrm{NMR} \\
(\mathrm{ppm})\end{array}$} \\
\hline & H (Arom.) & H (Aliph.) & \\
\hline 1 & $7.414-7.821(15 \mathrm{H})$ & $\mathrm{N}-\mathrm{CH}_{2}=3.719(2 \mathrm{H}) ; \mathrm{O}^{-\mathrm{CH}_{2}}=4.051(2 \mathrm{H}) ; \mathrm{N}-\mathrm{CH}_{3}=3.376(3 \mathrm{H}) ; \mathrm{O}^{-\mathrm{CH}_{3}}=3.514(3 \mathrm{H})$ & -183.84 \\
\hline 2 & $\begin{array}{l}7.439-7.861(15 \mathrm{H}) \\
7.163-7.393(10 \mathrm{H})\end{array}$ & $\mathrm{NCH}_{2}-\mathrm{Ben}=5.031(2 \mathrm{H}) ; \mathrm{NCH}_{2} \mathrm{CH}_{2}-\mathrm{Ar}=3.964(2 \mathrm{H}) ; \mathrm{NCH}_{2} \mathrm{CH}_{2}-\mathrm{Ar}=3.044(2 \mathrm{H})$ & -180.18 \\
\hline 3 & $7.408-7.767(15 \mathrm{H})$ & $\begin{array}{l}\left.\mathrm{N}-\mathrm{CH}_{3}=3.419(3 \mathrm{H}) ; \mathrm{N}-\mathrm{CH}_{2} \mathrm{CH}_{2} \mathrm{CH}_{2} \mathrm{CH}_{2} \mathrm{CH}_{2} \mathrm{CH}_{3}\right)=3.3838(2 \mathrm{H}) ; \\
\left.\left.\mathrm{N}-\mathrm{CH}_{2} \mathrm{CH}_{2} \mathrm{CH}_{2} \mathrm{CH}_{2} \mathrm{CH}_{2} \mathrm{CH}_{3}\right)=2.208(2 \mathrm{H}) ; \mathrm{N}^{-} \mathrm{CH}_{2} \mathrm{CH}_{2} \mathrm{CH}_{2} \mathrm{CH}_{2} \mathrm{CH}_{2} \mathrm{CH}_{3}\right)=1.753(2 \mathrm{H}) ; \\
\left.\left.\mathrm{N}-\mathrm{CH}_{2} \mathrm{CH}_{2} \mathrm{CH}_{2} \mathrm{CH}_{2} \mathrm{CH}_{2} \mathrm{CH}_{3}\right)=1.592(2 \mathrm{H}) ; \mathrm{N}-\mathrm{CH}_{2} \mathrm{CH}_{2} \mathrm{CH}_{2} \mathrm{CH}_{2} \mathrm{CH}_{2} \mathrm{CH}_{3}\right)=1.337(2 \mathrm{H}) ; \\
\left.\mathrm{N}-\mathrm{CH}_{2} \mathrm{CH}_{2} \mathrm{CH}_{2} \mathrm{CH}_{2} \mathrm{CH}_{2} \mathrm{CH}_{3}\right)=0.921(3 \mathrm{H})\end{array}$ & -187.56 \\
\hline
\end{tabular}


while the triplets at 3.964 and $3.044 \mathrm{ppm}$ are assigned to the methylene protons of the phenethyl group. In $0.921-3.838 \mathrm{ppm}$ region of ${ }^{1} \mathrm{H}$ NMR spectrum of compound $\mathbf{3}$, a few signals were observed, which can be attributed to the terminal methyl and methylene protons of the aliphatic hexyl chain.

Table-5 shows the ${ }^{13} \mathrm{C}$ NMR data for compounds 1-3. The chemical shifts of $\mathrm{CS}_{2}$ peak from $\mathrm{NCS}_{2}$ group is identified as the most significant shift to identify the dithiocarbamate moieties. This peak normally resonates in the range of 185-220 ppm [21]. In our case, the chemical shifts for $\mathrm{CS}_{2}$ carbon can be observed at $196.97,197.81$ and 196.04 for compounds $\mathbf{1}, \mathbf{2}$ and $\mathbf{3}$, respectively. The signals that appeared at 126-142 ppm can be assigned to the aromatic carbons of phenyl groups bound to the tin atom and benzyl carbons from compound 2. Other signals related to aliphatic carbons were also observed in the expected regions (Table-5).

${ }^{119} \mathrm{Sn}$ NMR chemical shift can be used to give tentative information of the environment around tin atoms [10]. The values of $\delta\left({ }^{119} \mathrm{Sn}\right)$ define the regions with different coordination numbers of the central tin atoms. Values in the ranges of +200 to -60 ppm, -90 to $-190 \mathrm{ppm}$, and -210 to $-400 \mathrm{ppm}$ of $\delta\left({ }^{119} \mathrm{Sn}\right)$ are attributed to four-coordinate compounds, five-coordinate compounds and six-coordinate compounds, respectively [22]. ${ }^{119} \mathrm{Sn}$ chemical shifts in the range -180 to $-188 \mathrm{ppm}$ were observed for all three compounds as presented in Table-4. Thus, it is expected that compounds 1-3 exist as five-coordinate compounds with bidentate function of dithiocarbamate ligands, which are further confirmed by the single crystal X-ray structures.

X-ray crystallography: The molecular structures of compounds 1-3 are shown in Fig. 3-5. Selected bond angles and bond lengths are presented in Table-6. The crystal structures showed that tin atoms are bonded to dithiocarbamate ligands in all three compounds. The dithiocarbamate ligands in all compounds coordinate to $\mathrm{Sn}(\mathrm{IV})$ in an asymmetrical manner [Sn$\mathrm{S} 1=2.4711(7), \mathrm{Sn}-\mathrm{S} 2=3.0180(7) \AA]$ compound $\mathbf{1}$, [Sn-S1 = 2.4886(4), $\mathrm{Sn}-\mathrm{S} 2=2.9120(3) \AA]$ compound 2 and $[\mathrm{Sn}-\mathrm{S} 1=$ 2.4672(11), Sn-S2 = 3.1112(12) ̊̊] compound 3 with $\Delta(\mathrm{Sn}-\mathrm{S})$, making the difference between the $\mathrm{Sn}-\mathrm{S}_{\text {long }}$ and $\mathrm{Sn}-\mathrm{S}_{\text {short }}$ bond lengths $0.55,0.42$ and $0.64 \AA$, respectively. The two metal-sulfur bonds in each compound are quite different but nevertheless within the expected range for a bonding interaction as they are smaller than the sum of Van der Waals radii of Sn and S (4.0 Å), reflecting a strong covalent character [4].

This data suggests an anisobidentate coordination mode of dithiocarbamate ligands [2]. This asymmetry is reflected in the relatively large disparity in the associated C-S bond lengths with the bond involving tightly bound $\mathrm{S} 1$ atom being significantly longer than the bond involving $S_{2}$ atom (Table-6). The $\mathrm{C}-\mathrm{S}$ bond length values are intermediate between the values

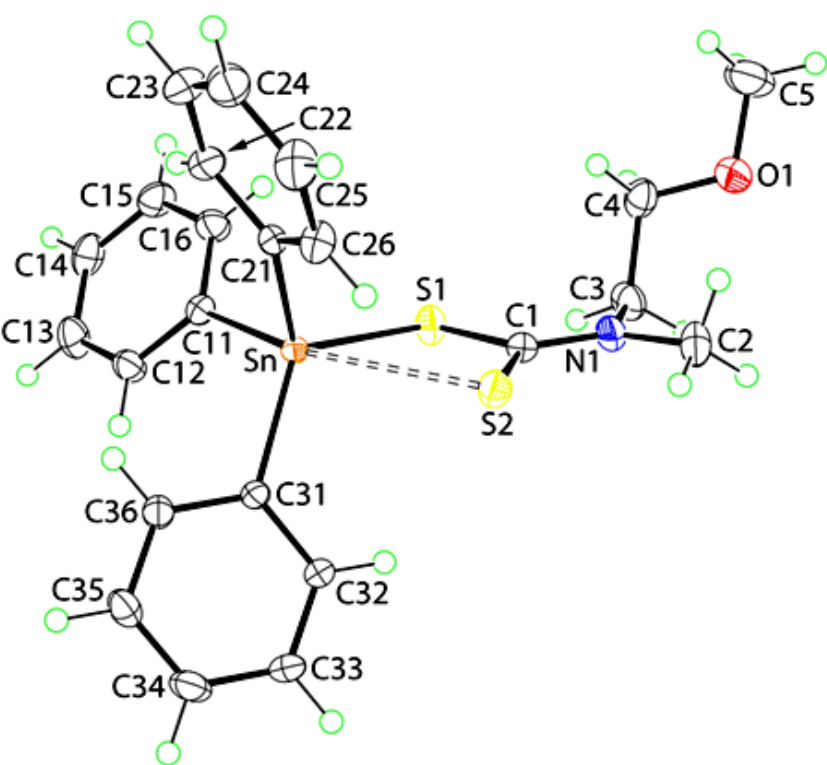

Fig. 3. Molecular structure of (1), showing the atom-labelling scheme and displacement ellipsoids at the $50 \%$ probability level

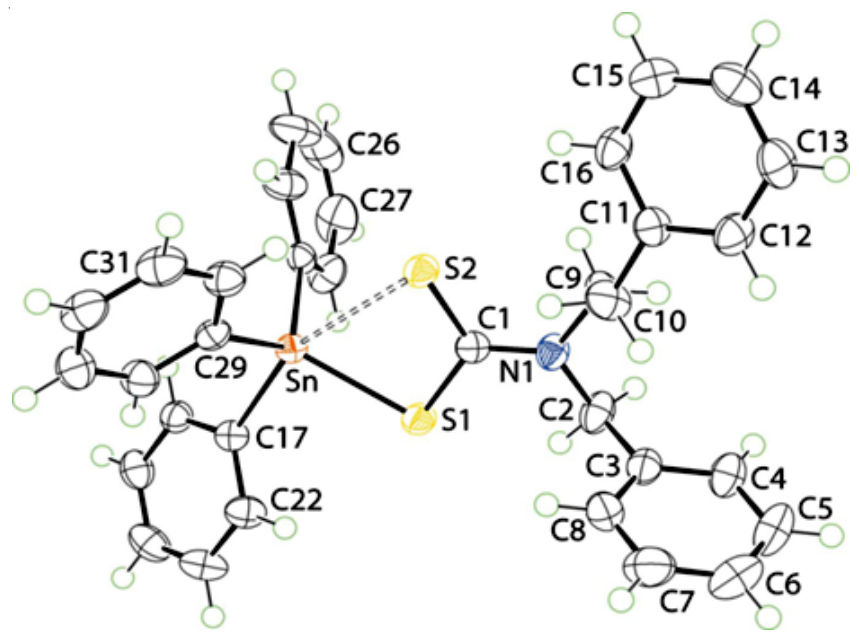

Fig. 4. Molecular structure of (2), showing the atom-labelling scheme and displacement ellipsoids at the $70 \%$ probability leve

expected for single $\mathrm{C}-\mathrm{S}$ bond $(1.82 \AA)$ and $\mathrm{C}=\mathrm{S}$ double bond $(1.60 \AA)$ [23]. The length of carbon-nitrogen (N1-C1) bond in all compounds is between the length of single C-N (1.46 $\AA$ ) and double bond $\mathrm{C}=\mathrm{N}(1.27 \AA)$ [23], which supports the carbonnitrogen double bond character as indicated in the IR spectrum by the presence of thioureide band.

The geometry at tin is best described as distorted trigonalbipyramidal in all three compounds, with the equatorial plane being defined by the two carbons of phenyl groups and a sulfur atom of dithiocarbamate ligands. The geometry around the $\mathrm{Sn}$

\begin{tabular}{|c|c|c|c|}
\hline \multirow{3}{*}{ Compound } & \multicolumn{3}{|r|}{$\begin{array}{c}\text { TABLE-5 } \\
{ }^{13} \text { C NMR DATA }\end{array}$} \\
\hline & \multicolumn{3}{|r|}{${ }^{13} \mathrm{C}$ NMR (ppm) } \\
\hline & $\mathrm{S}_{2} \mathrm{CN}$ & $\mathrm{C}$ (Arom.) & C (Aliph.) \\
\hline 1 & 196.97 & $128.25-142.28$ & $\mathrm{~N}-\mathrm{CH}_{2}=58.10 ; \mathrm{O}-\mathrm{CH}_{2}=70.09 ; \mathrm{N}-\mathrm{CH}_{3}=45.81 ; \mathrm{O}-\mathrm{CH}_{3}=59.06$ \\
\hline 2 & 197.81 & $126.73-142.33$ & $\mathrm{NCH}_{2}-\mathrm{Ben}=59.79 ; \mathrm{NCH}_{2} \mathrm{CH}_{2}-\mathrm{Ar}=56.37 ; \mathrm{NCH}_{2} \mathrm{CH}_{2}-\mathrm{Ar}=32.82$ \\
\hline 3 & 196.04 & $128.52-142.53$ & 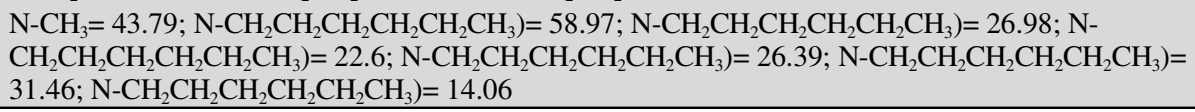 \\
\hline
\end{tabular}




\begin{tabular}{|c|c|c|c|c|c|}
\hline \multicolumn{6}{|c|}{$\begin{array}{c}\text { TABLE-6 } \\
\text { GEOMETRIC DATA }\left(\AA,^{\circ}\right) \text { FOR COMPOUNDS } \mathbf{1 - 3}\end{array}$} \\
\hline \multicolumn{6}{|c|}{ Bond length $(\AA)$} \\
\hline \multicolumn{2}{|c|}{ Compound 1} & \multicolumn{2}{|c|}{ Compound $\mathbf{2}$} & \multicolumn{2}{|c|}{ Compound $\mathbf{3}$} \\
\hline Sn-S1 & $2.4711(7)$ & $\mathrm{Sn}-\mathrm{S} 1$ & $2.4886(4)$ & Sn-S1 & $2.4672(11)$ \\
\hline $\mathrm{Sn} \cdots \mathrm{S} 2$ & $3.0180(8)$ & $\mathrm{Sn}-\mathrm{S} 2$ & $2.9120(3)$ & $\mathrm{Sn} \cdots \mathrm{S} 2$ & $3.1112(12)$ \\
\hline $\mathrm{S} 1-\mathrm{C} 1$ & $1.755(3)$ & $\mathrm{S} 1-\mathrm{C} 1$ & $1.7532(13)$ & $\mathrm{S} 1-\mathrm{C} 1$ & 1.761(4) \\
\hline $\mathrm{S} 2-\mathrm{C} 1$ & $1.686(3)$ & $\mathrm{S} 2-\mathrm{C} 1$ & $1.6902(13)$ & $\mathrm{S} 2-\mathrm{C} 1$ & $1.688(4)$ \\
\hline $\mathrm{Sn}-\mathrm{C} 31$ & $2.133(2)$ & $\mathrm{Sn}-\mathrm{C} 17$ & $2.1696(13)$ & $\mathrm{Sn}-\mathrm{C} 31$ & $2.156(4)$ \\
\hline $\mathrm{Sn}-\mathrm{C} 21$ & $2.136(3)$ & $\mathrm{Sn}-\mathrm{C} 23$ & $2.1309(13)$ & $\mathrm{Sn}-\mathrm{C} 21$ & $2.123(4)$ \\
\hline $\mathrm{Sn}-\mathrm{C} 11$ & $2.162(3)$ & $\mathrm{Sn}-\mathrm{C} 29$ & $2.1469(13)$ & $\mathrm{Sn}-\mathrm{C} 11$ & $2.159(4)$ \\
\hline $\mathrm{N} 1-\mathrm{C} 1$ & $1.333(4)$ & $\mathrm{N} 1-\mathrm{C} 1$ & $1.3305(18)$ & $\mathrm{N} 1-\mathrm{C} 1$ & $1.330(5)$ \\
\hline \multicolumn{6}{|c|}{ Bond angles $\left({ }^{\circ}\right)$} \\
\hline \multicolumn{2}{|c|}{ Compound 1} & \multicolumn{2}{|c|}{ Compound $\mathbf{2}$} & \multicolumn{2}{|c|}{ Compound $\mathbf{3}$} \\
\hline $\mathrm{C} 31-\mathrm{Sn}-\mathrm{C} 11$ & $105.78(10)$ & $\mathrm{S} 1-\mathrm{Sn}-\mathrm{S} 2$ & $65.919(10)$ & $\mathrm{C} 21-\mathrm{Sn}-\mathrm{C} 31$ & $112.73(14)$ \\
\hline $\mathrm{C} 21-\mathrm{Sn}-\mathrm{C} 11$ & $104.11(10)$ & S2-Sn-C17 & $158.55(4)$ & $\mathrm{C} 21-\mathrm{Sn}-\mathrm{C} 11$ & $114.88(15)$ \\
\hline C31-Sn-S1 & $119.09(7)$ & C29-Sn-C17 & $101.34(5)$ & C31-Sn-C11 & $104.73(15)$ \\
\hline $\mathrm{C} 21-\mathrm{Sn}-\mathrm{S} 1$ & $115.84(7)$ & C17-Sn-S1 & $92.98(4)$ & $\mathrm{C} 21-\mathrm{Sn}-\mathrm{S} 1$ & $109.94(11)$ \\
\hline C11-Sn-S1 & $91.17(8)$ & $\mathrm{C} 23-\mathrm{Sn}-\mathrm{S} 1$ & $108.24(4)$ & C31-Sn-S1 & $90.00(11)$ \\
\hline $\mathrm{C} 1-\mathrm{S} 1-\mathrm{Sn}$ & $96.57(10)$ & $\mathrm{C} 29-\mathrm{Sn}-\mathrm{S} 1$ & $124.31(4)$ & C11-Sn-S1 & $121.53(10)$ \\
\hline
\end{tabular}

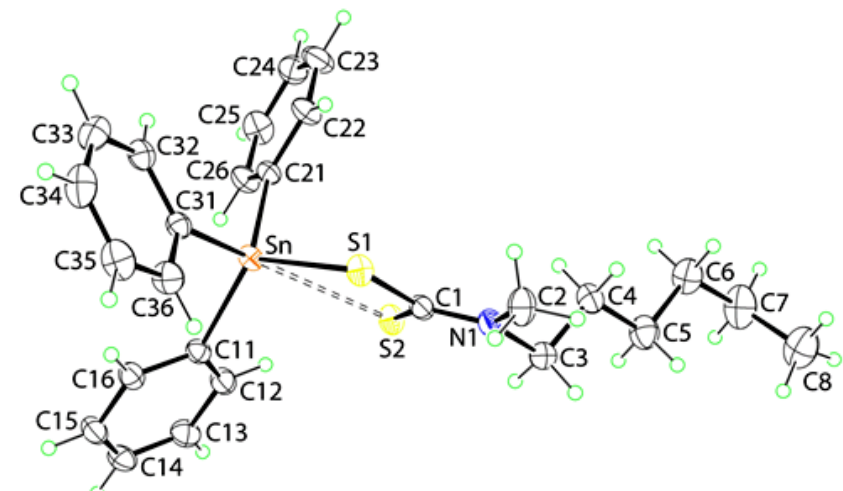

Fig. 5. Molecular structure of (3), showing the atom labelling scheme and displacement ellipsoid at $35 \%$ probability level

atom can be characterized by the value of $\tau$; an indicator of a five-coordinate coordination geometry with $\tau$ values of 0.0 and 1.0 being ideal square-pyramidal and trigonal-bipyramidal geometries, respectively [24]. The geometry found is not ideal, with $\tau$ values of 0.61 (compound 1), 0.57 (compound 2) and 0.52 (compound 3). For compound 1, the value indicated a distorted trigonal-bipyramidal arrangement around $\mathrm{Sn}$ atom with $\mathrm{C} 11$ from a phenyl group and $\mathrm{S}_{2}$ from dithiocarbamate ligand in the axial positions while $\mathrm{C} 21$ and $\mathrm{C} 31$ from two phenyl groups and $\mathrm{S} 1$ in the planar positions. The sum of equatorial angles, $\left[\mathrm{C} 31-\mathrm{Sn}-\mathrm{C} 21=115.55(10)^{\circ}, \mathrm{C} 31-\mathrm{Sn}-\mathrm{S} 1=119.09(7)^{\circ}\right.$ and C21$\left.\mathrm{Sn}-\mathrm{S} 1=115.84(7)^{\circ}\right]$, is $350.48^{\circ}$ instead of the ideal $360^{\circ}$. Being a part chelate, the angle $\mathrm{S} 2-\mathrm{Sn}-\mathrm{S} 1$ is only $64.37^{\circ}$, thus $\mathrm{S}_{2}$ does not occupy the exact corresponding trans apical position of $\mathrm{C} 11$, with the angle between the apical groups being $155.54^{\circ}$ [18].

The same pattern can be observed in the distorted trigonalbipyramidal arrangement of compounds $\mathbf{2}$ and $\mathbf{3}$ around Sn atom with [C17 and S2] compound $\mathbf{2}$ and [C31 and S2] compound $\mathbf{3}$ in the axial positions while [C23, C29 and S1] compound 2 and [C11, C31 and S1] compound 3 in the planar positions. The equatorial angles, [C29-Sn-S1 = 124.31 (4) ${ }^{\circ}$, C29-Sn-C23 $=118.33(5)^{\circ}$ and $\left.\mathrm{C} 23-\mathrm{Sn}-\mathrm{S} 1=108.24(4)^{\circ}\right]$ compound 2 and $\left[\mathrm{C} 11-\mathrm{Sn}-\mathrm{C} 21=114.88(15)^{\circ}, \mathrm{C} 21-\mathrm{Sn}-\mathrm{S} 1=109.94(11)^{\mathrm{o}}\right.$ and $\left.\mathrm{C} 11-\mathrm{Sn}-\mathrm{S} 1=121.53(10)^{\circ}\right]$ compound 3 total up to $350.88^{\circ}$ for compound 2 and $345.35^{\circ}$ for compound 3. Meanwhile, the S2-Sn-S1 is only $65.92^{\circ}$ (compound 2) and $63.26^{\circ}$ (compound 3 ) instead of the ideal $90^{\circ}$. Distortions from the ideal can be related to dissimilar $\mathrm{Sn}$-donor atom bond lengths and the acute chelate angle [25].

\section{Conclusion}

In this study, three new triphenyltin(IV) compounds featuring $N$-(2-methoxyethyl)- $N$-methyldithiocarbamate (1), $N$ benzyl- $N$-phenethyldithiocarbamate (2) and $N$-methyl- $N$-hexyldithiocarbamate (3) ligands have been successfully synthesized and characterized. Spectroscopic studies suggest a bidentate coordination mode of all three dithiocarbamato ligands, which are supported by X-ray crystallographic data. The bidentate ligands are found to be asymmetrical in manner, which is also commonly known as an isobidentate. The geometry around tin metal center is best described as distorted trigonal-bipyramidal in all the crystal structures of compounds 1-3.

Supplementary information: CCDC reference numbers (1821128, 1505733 and 1833664) contain the supplementary crystallographic data for the compounds $\mathbf{1 - 3}$. These data can be obtained via http://www.ccdc.cam.ac.uk/conts/retrieving.html, or from the Cambridge Crystallographic Data Centre, 12 Union Road, Cambridge CB21EZ, UK; Fax: +44 1223336 033; or E-mail: deposit@ccdc.cam.ac.uk.

\section{ACKNOWLEDGEMENTS}

This work was supported by the grant FRGS/2/2013/SKK10/ UKM/02/1 and GUP-2018-062. The authors gratefully acknowledge to School of Chemical Sciences and Food Technology of Universiti Kebangsaan Malaysia for providing the essential laboratory facilities. The authors also thank the laboratory assistants of the Faculty of Science and Technology, Universiti Kebangsaan Malaysia for their technical support. The intensity data were collected at University of Malaya's Crystallographic Laboratory.

\section{CONFLICT OF INTEREST}

The authors declare that there is no conflict of interests regarding the publication of this article. 


\section{REFERENCES}

1. R.S. Herrick, C.J. Ziegler, S. Sripothongnak, N. Barone, R. Costa, W. Cupelo and A. Gambella, J. Organomet. Chem., 694, 3929 (2009); https://doi.org/10.1016/j.jorganchem.2009.08.008.

2. G. Hogarth, Mini Rev. Med. Chem., 12, 1202 (2012); https://doi.org/10.2174/138955712802762095.

3. L. Tian, X. Zheng, X. Zheng, Y. Sun, D. Yan and L. Tu, Appl. Organomet. Chem., 25, 785 (2011); https://doi.org/10.1002/aoc. 1834 .

4. I.P. Ferreira, G.M. de Lima, E.B. Paniago, W.T. Rocha, J.A. Takahashi, C.B. Pinheiro and J.D. Ardisson, Eur. J. Med. Chem., 58, 493 (2012); https://doi.org/10.1016/j.ejmech.2012.10.021.

5. A. Varela-Ramirez, M. Costanzo, Y.P. Carrasco, K.H. Pannell and R.J. Aguilera, Cell Biol. Toxicol., 27, 159 (2011); https://doi.org/10.1007/s10565-010-9178-y.

6. A.-L. Lainé and C. Passirani, Curr. Opin. Pharmacol., 12, 420 (2012); https://doi.org/10.1016/j.coph.2012.04.006.

7. M. Gielen, Appl. Organomet. Chem., 16, 481 (2002); https://doi.org/10.1002/aoc.331.

8. M.K. Amir, S. Khan, Zia-ur-Rehman, A. Shah and I.S. Butler, Inorg. Chim. Acta, 423, 14 (2014); https://doi.org/10.1016/j.ica.2014.07.053.

9. I.P. Ferreira, G.M. de Lima, E.B. Paniago, W.R. Rocha, J.A. Takahashi, C.B. Pinheiro and J.D. Ardisson, Polyhedron, 79, 161 (2014); https://doi.org/10.1016/j.poly.2014.05.001.

10. N. Khan, Y. Farina, L.K. Mun, N.F. Rajab and N. Awang, J. Mol. Struct., 1076, 403 (2014); https://doi.org/10.1016/j.molstruc.2014.08.015.

11. Agilent.CrysAlis PRO. Agilent Technologies Inc., Santa Clara, CA, USA (2015).

12. G.M. Sheldrick, Acta Crystallogr. A, 64, 112 (2008); https://doi.org/10.1107/S0108767307043930.
13. G.M. Sheldrick, Acta Crystallogr. C, 71, 3 (2015); https://doi.org/10.1107/S2053229614024218.

14. L.J. Farrugia, J. Appl. Cryst., 45, 849 (2012); https://doi.org/10.1107/S0021889812029111.

15. K. Brandenburg, DIAMOND Crystal Impact GbR, Bonn, Germany (2006).

16. Y. Farina, A.H. Othman, I. Baba, S.W. Ng and H.-K. Fun, Main Group Met. Chem., 25, 67 (2002); https://doi.org/10.1515/MGMC.2002.25.1-2.67.

17. F. Bonati and R. Ugo, J. Organomet. Chem., 10, 257 (1967); https://doi.org/10.1016/S0022-328X(00)93085-7.

18. Z.U. Rehman, A. Shah, N. Muhammad, S. Ali, R. Qureshi, A. Meetsma and I.S. Butler, Eur. J. Med. Chem., 44, 3986 (2009); https://doi.org/10.1016/j.ejmech.2009.04.031.

19. O.S. Jung, J. Hwa Jeong and Y.S. Sohn, Polyhedron, 8, 1413 (1989); https://doi.org/10.1016/S0277-5387(00)86254-3.

20. L. Giovagnini, L. Ronconi, D. Aldinucci, D. Lorenzon, S. Sitran and D. Fregona, J. Med. Chem., 48, 1588 (2005); https://doi.org/10.1021/jm049191x.

21. H.L.M. Van-Gaal, J.W. Diesveld, F.W. Pijpers and J.G.M. Van der Linden, Inorg. Chem., 18, 3251 (1979); https://doi.org/10.1021/ic50201a062.

22. J. Holeèek, M. Nádvorník, K. Handlíø and A. Lyèka, J. Organomet. Chem., 315, 299 (1986); https://doi.org/10.1016/0022-328X(86)80450-8.

23. P.F. Lindley and P. Carr, J. Crys. Mol. Struct., 4, 173 (1974); https://doi.org/10.1007/BF01197912.

24. A.W. Addison, T.N. Rao, J. Reedijk, J. van Rijn and G.C. Verschoor, J. Chem. Soc., Dalton Trans., 1349 (1984); https://doi.org/10.1039/DT9840001349.

25. R. Mohamad, N. Awang, N.F. Kamaludin, M.M. Jotani and E.R.T. Tiekink, Acta Crystallogr. Sect. E Struct. Rep. Online, 72, 1480 (2016); https://doi.org/10.1107/S2056989017001098. 